\title{
Research Paper \\ The Relationship between Cognitive Characteristics and Parental Satisfaction with Birth Weight
}

\section{Fatemeh Zeidabadinejad ${ }^{1}$, Mehdi Davaee ${ }^{* 2}$, Golamali Afrooz ${ }^{3}$}

1. Ph.D.Student of Psychology and Education of Exceptional Children, Science and Research Branch, Islamic Azad University, Tehran, Iran

2. Assistant Professor, Department of Education and Training, Central Tehran Branch, Islamic Azad University, Tehran, Iran 3. Professor, Department of Psychology and Exceptional Children, Faculty of Psychology and Educational Sciences, University of

Tehran, Iran

Citation: Zeidabadinejad F, Davaee M, Afrooz G. The relationship between cognitive characteristics and parental satisfaction with birth weight. Quarterly Journal of Child Mental Health. 2019; 6(3): 66-77.

http://dx.doi.org/10.29252/jcmh.6.3.7

\section{A R T I C L E I N F O}

\section{Keywords:}

Birth weight, marital satisfaction, cognitive characteristics

Received: 7 May 2018 Accepted: 26 Oct 2018 Available: 9 Nov 2019

\section{A B S T R A C T}

Background and Purpose: The birth's weight is the most important factor in child's survival and growth. In fact, this factor is one of the community health status indicators and is directly related to several factors, including parental characteristics. This study was conducted to determine the relationship between marital satisfaction and cognitive characteristics of parents with birth weight. Method: This study was a correlational research. A sample of 70 parents of low birth weight infants and parents of high birth weight infants (35 per group) were selected randomly from Imam Reza Hospital in Sirjan in 2016. To collect data, Marital Satisfaction Questionnaire (Afrooz, 2008) and the Bio-Cognitive Characteristics Questionnaire (Afrooz, 2004) were used. Chi-square, fisher, mannwhitney, and multiple logistic regressions were used for data analysis.

Results: The results showed that there was a significant relationship between the birth weight of the newborns and the level of marital satisfaction $(\mathrm{OR}=8.887, \mathrm{P}=0.039)$, mothers' awareness of pregnancy conditions $(\mathrm{OR}=0.486, \mathrm{p}=0.010)$ and father's awareness of pregnancy conditions $(\mathrm{OR}=$ $30.795, p=0.010$ ). In a way that increase of these characteristics increases the likelihood of high birth weight infant. Also, no signification relationship was found between the birth weight and the education of fathers $(\mathrm{p}=0.395)$ and mothers $(\mathrm{p}=0.778)$.

Conclusion: One of the most important issues in preventing the disabilities is the birth weight. Considering the influence of factors such as cognitive characteristics and marital satisfaction on infant's weight, it is possible to provide the appropriate pregnancy conditions and high quality pregnancy care by increasing the awareness and the necessity of paying attention to these areas.

\footnotetext{
* Corresponding author: Mehdi Davaee, Assistant Professor, Department of Education and Training, Central Tehran Branch, Islamic Azad University, Tehran, Iran.

E-mail addresses: Davaee@yahoo.com
}

2476-5740/ (C) 2019 The Authors. This is an open access article under the CC BY-NC-ND license (https://creativecommons.org/licenses/by-nc-nd/3.0/). 


\section{رابطه ويزّى هاى شناختى و رضايتمندى والدين با وزن نوزاد به هنتام تولد}

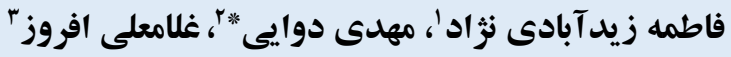

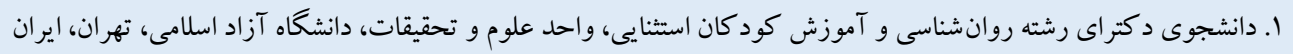

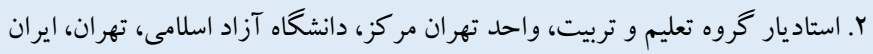

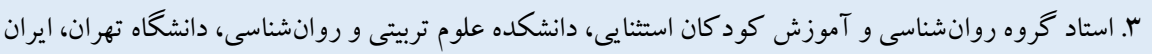

زمينه و هدف: وزن نوزاد به هنكام تولد مهم ترين عامل بقاو تحول او در سـالهاى آينده است. اين شـاخص يكى از نشانكرهاى وضعيت

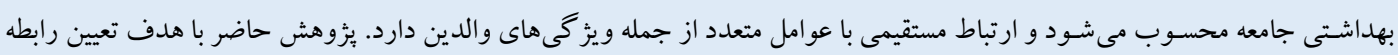

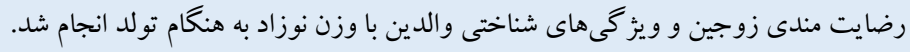

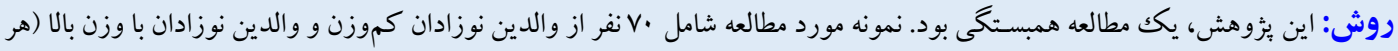

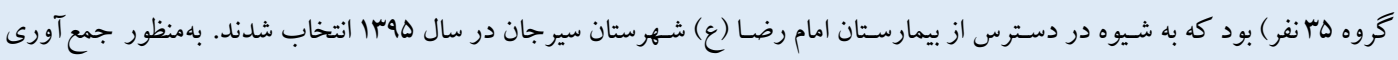

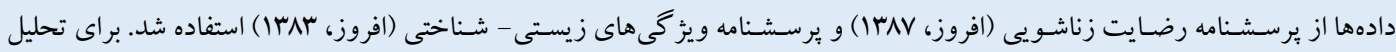

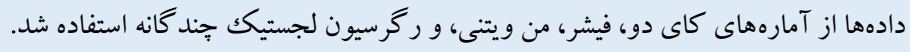

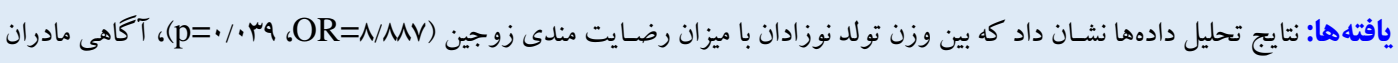

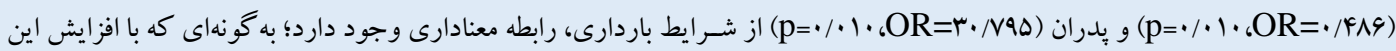

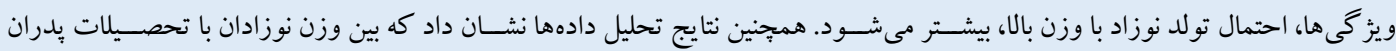
(p=•/WVA) رابطه معنادارى ييدا نشد.

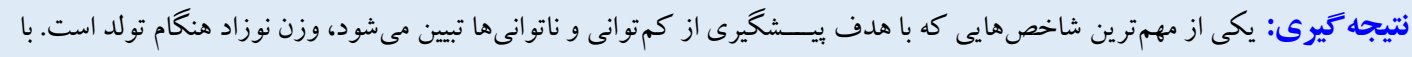

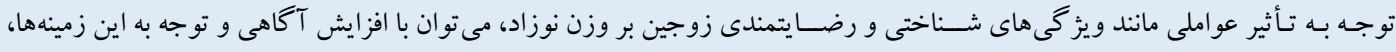

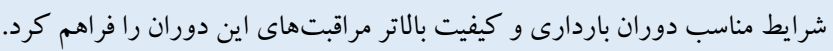

مشخصات مقاله

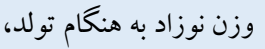

رضايت مندى زوجين،

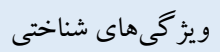

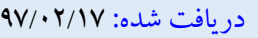

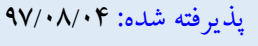
منتشر شده: M

* نويسنده مسئول: مهدى دوايى، استاديار گروه تعليم و تربيت، واحد تهران مركز، دانشكاه آزاد اسلامى، تهران، ايران.

راياناهם: Davaee@yahoo.com 
وزن طبيعى اسـت و اين كود كان حتّى از نظر مر گكومير تا قبل از سن" 10

مقدمه

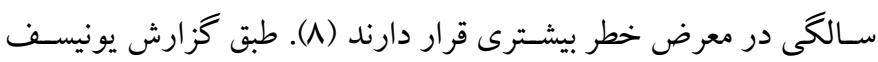

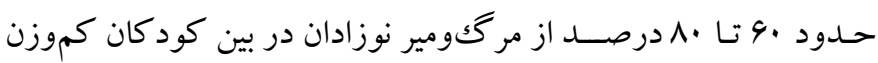

مشاهده مىشود (9). (9)

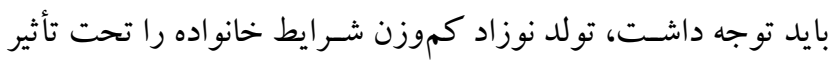

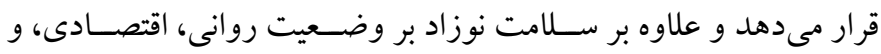

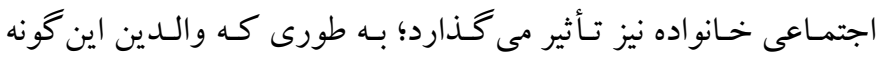

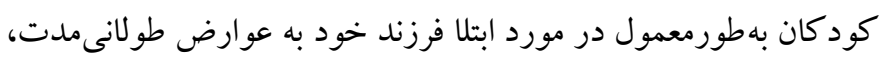

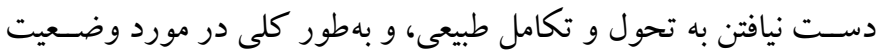
سلامت و طبيعى بودن فرزند خود، دجار نخر انى و اضطر اب هستند ( •(1).

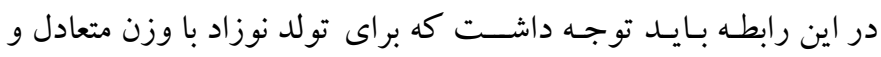

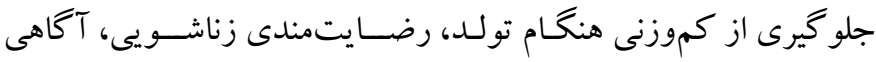

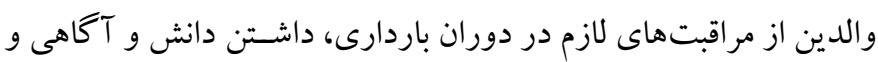

شناخت كافى، ضرورى است (11).

رضـايـتمنـدى زوجين يكى از عوامل تعيين كننده ثبات و وبايدارى

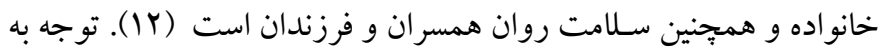
رضـايـت مندى زوجين به دليل نقش آن در ســلامت جسـمـى و روانى

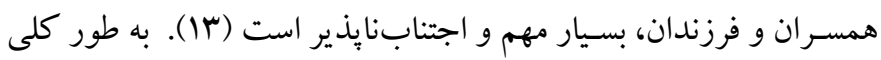
اين اصطلاح به رضايت متقابل زن و شوهر از جاذبه هاى روانى - جنسى

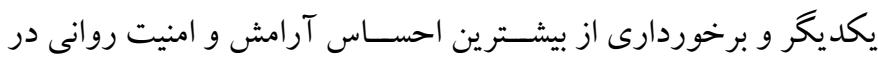

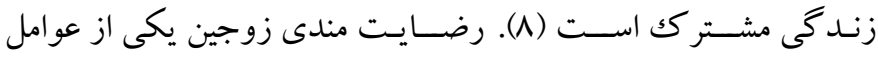

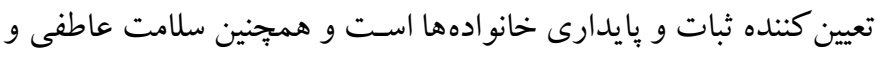

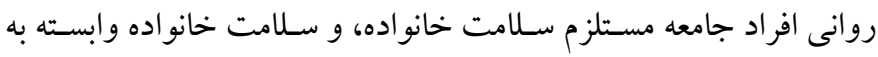

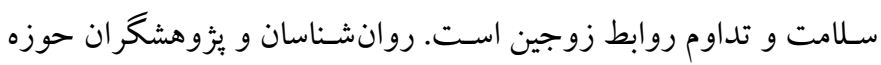

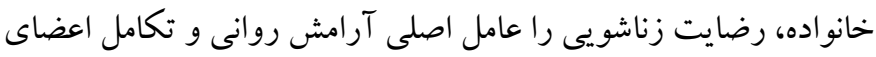
خانواده برشمردهاند و به عوامل مؤثر در رضايت زناشويى زوجين اهميت

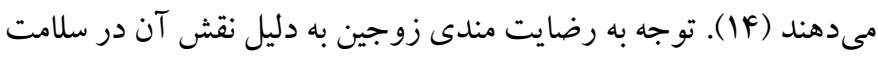
روانى همسر ان و فرزندان، اجتنابنايذير است. تولد كود كك نشانه تغييرى

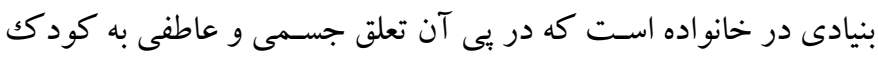
مستلزم تغيير در الكوهاى ارتباط زن و شـوهر مى شود و و والدين را وادار 
مطالعه هرد` در آمريكا هم نشـان داده شـد كه سـطح تحصيلات والدين، ييش بينى كننده مهمى براى سلامت افراد است. همجنين در همه كشورها

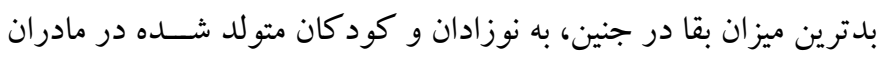

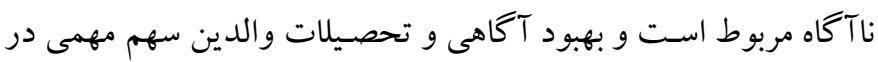
بقـا جنين و كود كـان دارد. اين موضـــوع مهم از تُند طريق مانند در آمد

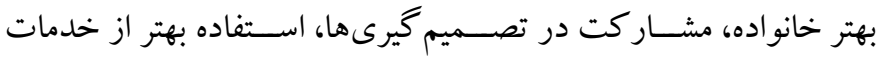
موجود، و فراهم كردن مراقبت بهتر از كود كان و تغذيه مناسب با سلامت

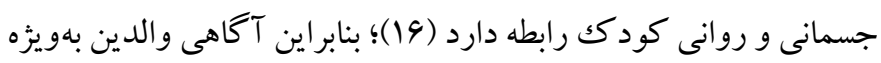
مادر درباره مسـائل دوران باردارى، تضـمين كننده سلامت نوزاد درد ابعاد جسـمى از جمله وزن جنين و نوزاد اسـت (19 و IV). همجنين ترديدى

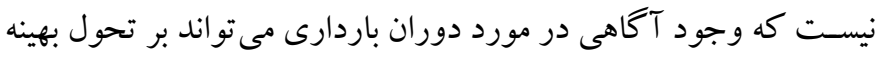

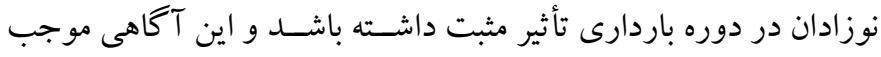

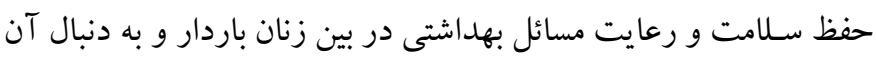

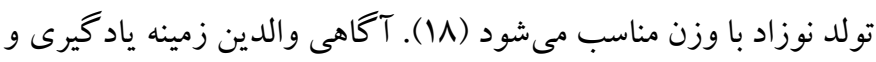

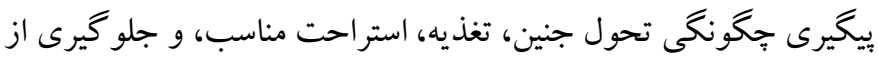

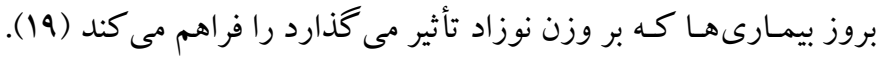

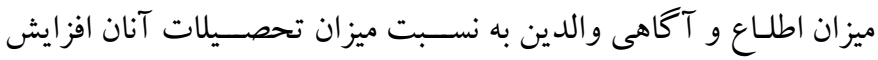

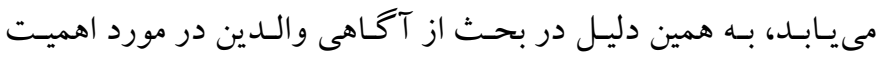

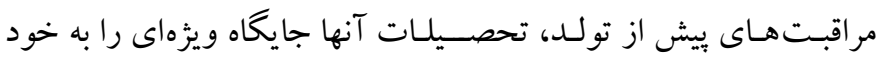

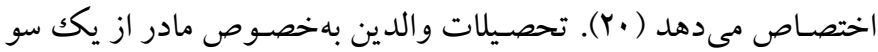

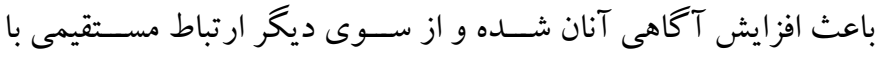

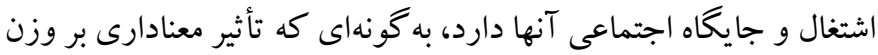

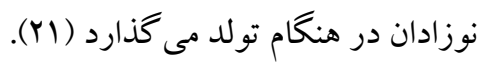

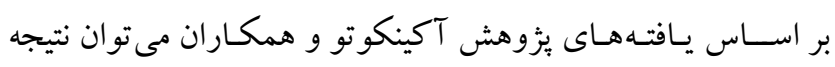

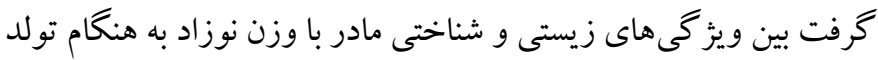
ارتبـاط وجود دارد و اين ويزگى هـا مى تو انند بهعنوان عامل تأثير كذار بر

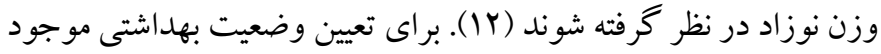

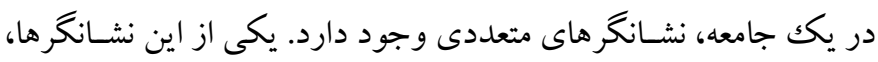

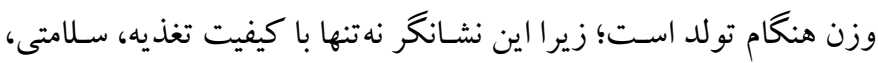

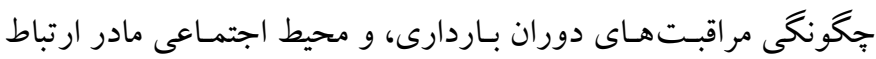

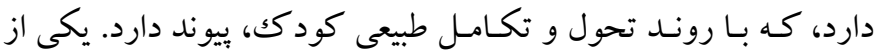

\section{Herd}

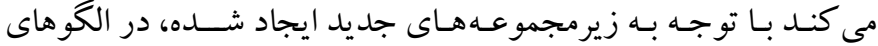
رفتـارى خود تغييراتى بــدهنـد تا بتوانند با شــــايط جديد ســازش يابند. والـدين همجينين بايد از دخالت دادن مســائل مربوط به فرزند در روابط

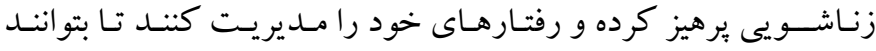
رضـايتمندى خويش را از همديخر حفظ كنند. نارضـايتى زناشــويى، بسيارى از زنان را در دوران باردارى دجار احساس آسيب يذيرى مى كند كه نهايتاً مى تواند به كموزنى نوزاد منجر شـود (سا). عدم رضـايتمندى

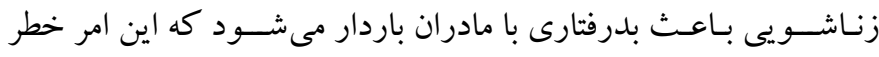
خونريزى قبـل از زايمـان و محـدوديـت تحول جنين را افزايش مىدهـد (ها). يافته يزووهش جى ' نشـان داد وجود رضايتمندى زوجين مى تواند علاوه بر تأثيرات مثبت در تمامى زمينها، بخش زيادى از سلامت جنين و به دنبال آن سلامت فرزندان و خانو اده را فراهم سازد (1). همخينين، يافته يثزوهش بِارسـا، افروز، لواسـانى، و جشنى مطلق نشان داد وجود رضايت

مندى زوجين مى تواند بر وزن نوزاد به هنگام تولد تأثير بـذارد (ه).

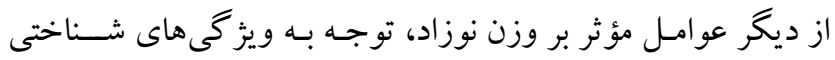
والـدين اســـ؛ ويز گَى هـاى شـــاختى بهعنوان مجموعهاى از متغيرهاى شــاختى اسـت كه شــامل ميزان تحصـيلات بدر و مادر، ميزان آكاهى والدين درباره كنش هاى حسى -حركتى جنين، و نيازهاى اساسى مادر در دوران باردارى مانند خواب و تغذيه اسـت (V). ترديدى نيست كه ميزان آخَاهى والدين به نســبت ميزان تحصــيلات آنان افزايش مى يابد. بدين ترتيـب در بحث از اشــراف والدين به اهميت مراقبتهاى بيش از تولد، تحصيلات و آكاهى آنان جايگاه ويزهاى به خود اختصاص مىدهد. بدين ترتيب، تحصـيلات والدين از يككسـو باعث افزايش آكاهى تخصسصى آنان شــهـ و از سـوى ديخر با وضسعيت سـلامت نوزاد و خانواده مرتبط مى شود (9)؛ بنابر اين، سطح آموزشى و آكاهى بالاى والدين بهويزه مادر، جنين و نوزاد را در برابر بسيارى از بيمارىها و آسيبها از جمله كموزنى هنخـام تولـد محافظت مى كند (سا). در اين ارتباط در يثروهشـى درباره علل كموزنى نوزاد، متغيرهـايى مانند بـىســواد بودن مادر، و وضسـعيت نـامطلو ب اجتمـاعى - اقتصــادى بـه عنوان عو امل بســيار مهم تأثير خذار شـناسايى شدهاند (f ( ). از سويى ديخر، تحصيلات بالاتر والدين و در آمد خانو اده، دسـترسى به خدمات سـلامت مادر و نوزاد را فراهم مى كند. در
1. Chee 
سال، ميانخين سن بدر ابم سال، و بيشتر والدين داراى تحصيلات ديبلم و

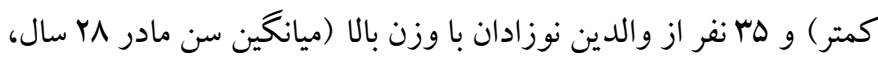

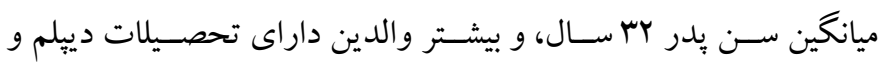

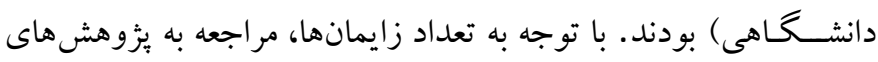
مشـابه و محدوديت هاى خاص اجر ايى در اين مطالعه، حجم نمونه مورد

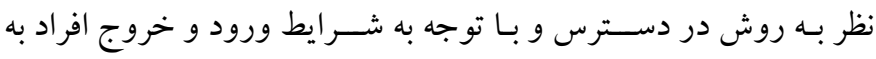

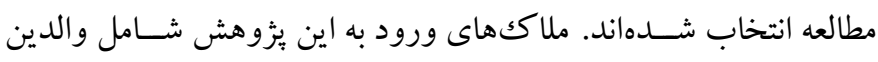

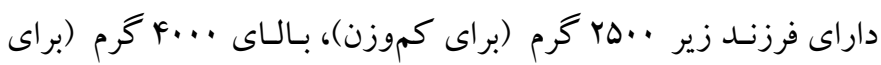

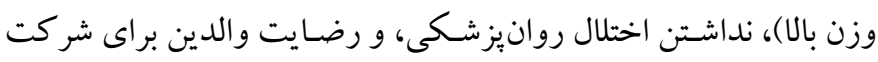

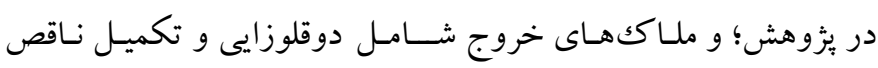

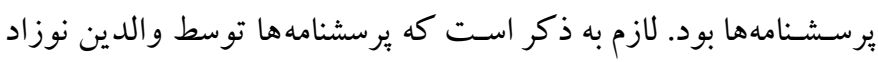

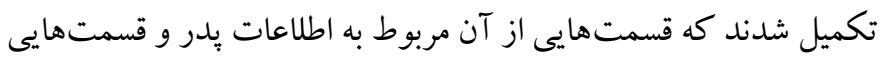

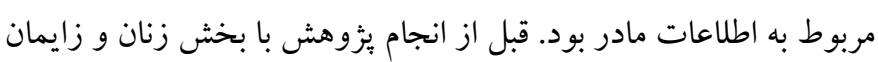

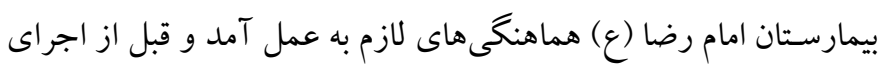

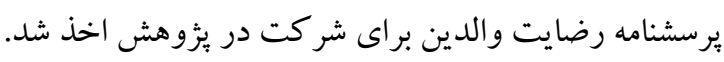

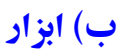

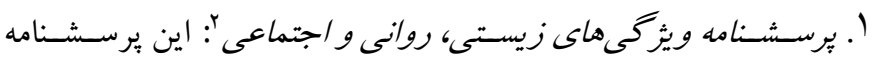

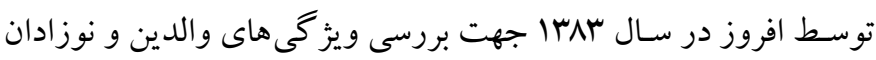

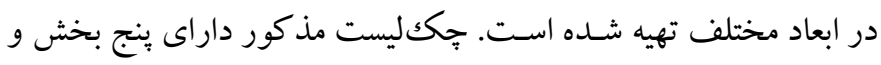

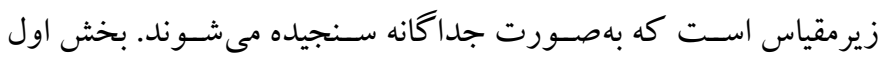

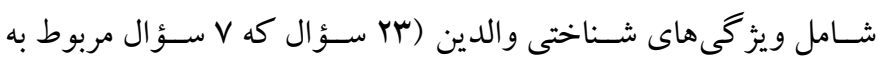

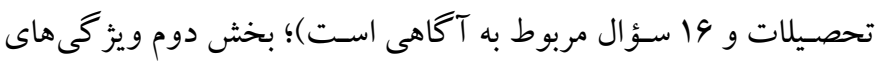

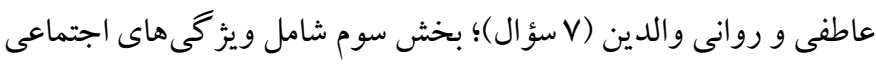

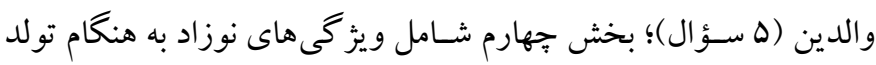

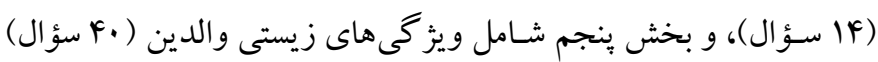

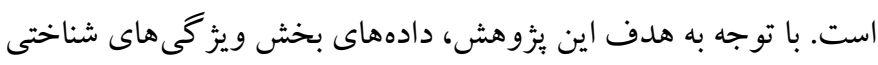

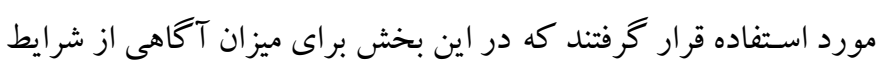

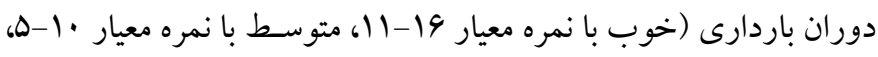

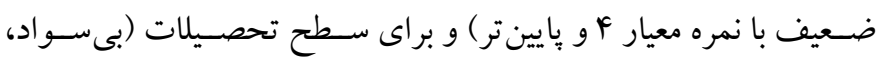

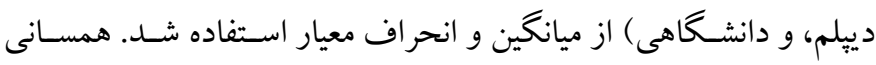

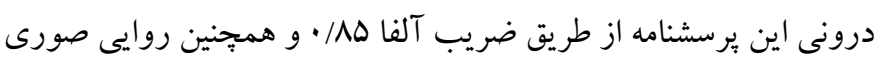

اهداف سـازمان سـلامت جهانى' در كشـورهاى در حال توسعه آن است

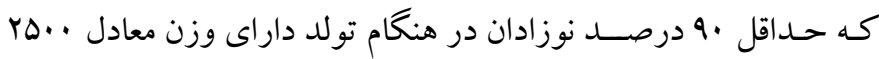

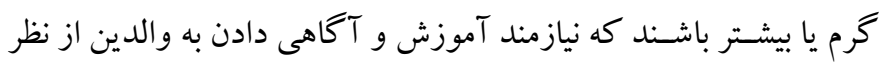

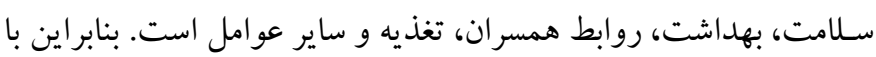

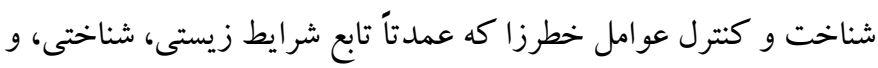

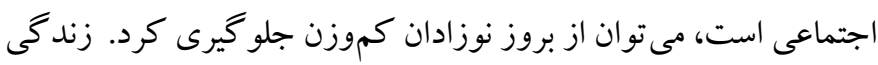

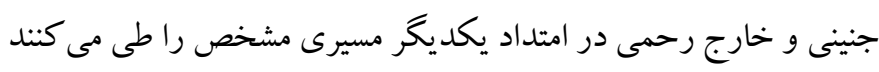

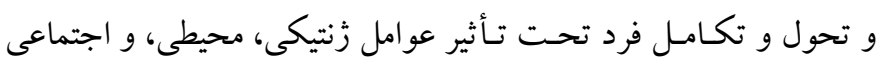

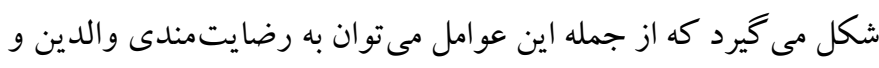
تحصيلات و آكاهى آنها اشاره كرد. شناخت عوامل مؤثر در تحول جنين آنين

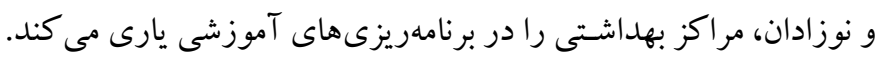

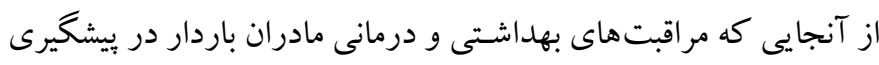

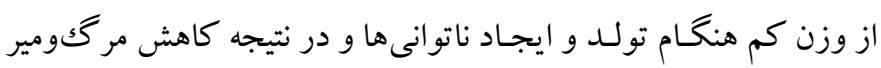
نوزادان اهميت بهسـزايى دارد، شــاخت عوامل مؤثر در اين زمينه بسـيار

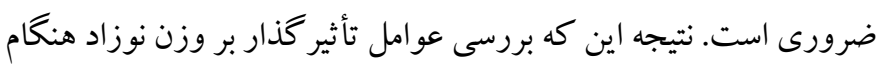

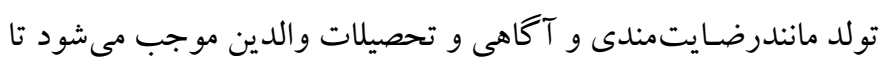

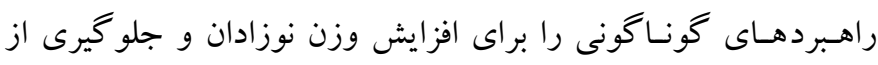

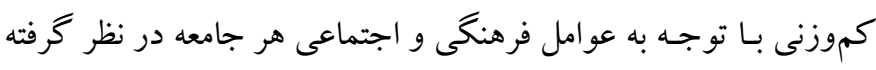

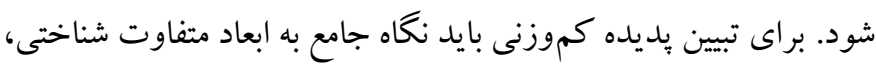

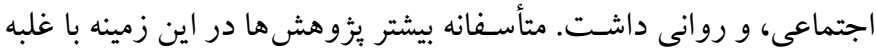

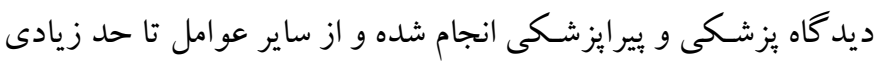

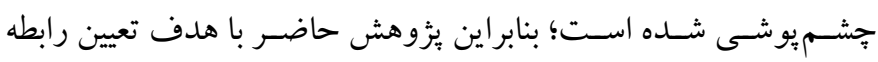

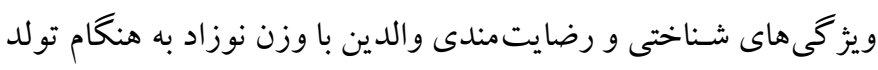

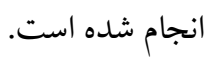

روش الف) طرح يزوهش و شــ كت كنند كان: روش بثزوهش حاضر از نوع

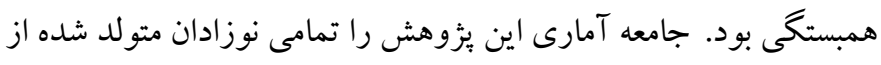

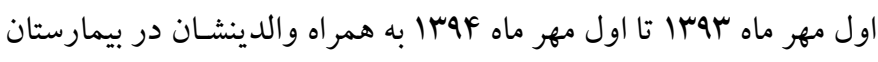

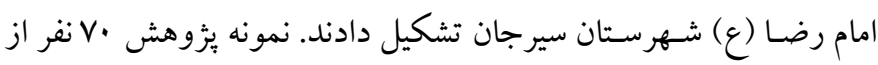

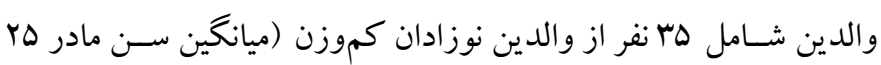


سير جان رجوع شد و با توجّه به مشخص بودن فهرست نوزادان و يرونده زايمـانهـاى موجود از اول مهر به تـا اول مهر هو، اطلـاعـات للزم مورد بررسى و ثبت قرار كرفت و سـيس برسشنامهها توسط •V نفر از والدين كه داراى ملاكك ورود به بزوهش بودند، تكميل شدند. للازم به ذكر است كه تمامى ملاحظات اخلاقى مانند رعايت اصل رازدارى و محرمانه ماندن اطلاعات و رضـايت كتبى والدين در اجراى اين مطالعه رعايت شــد. در نهـايت دادههاى جمع آورى شــده با اســتفاده از نرمافزار SPSS مورد بررسى و تجزيهو تحليل قرار كرفت.

\section{يافتهها}

در اين مطالعه ويزً كى هاى شـناختى و رضـايت مندى زوجين ها مادر و يــدر داراى فرزنـد بـا وزن بـالـا و هب مادر و يدر داراى فرزند با وزن كم هنگام تولد مورد بررسـى قرار گرفت. ابتدا اطلاعات توصسيفى مربوط به متغيرهاى جمعيت شناختى از جمله وزن نوزاد هنگام تولد، رتبه تولد، سن مادران باردار و همسـرانشـان و سن ازدواج هر يكك از آنها، نوع ازدواج، آگتاهى مادر از شــــايط دور ان باردارى، آكاهى يدر از شــــايط دوران باردارى، جنسـيت نوزاد، رضـايتمندى، و ميزان تحصسيلات مادر و بـدر ارائه شـده است. سيس ميانگين و انحر اف معيار متغيرهاى بثزوهش شامل رضـايت مندى، آكاهى مادران و بِران، و تحصسيلات مادران و يدران در دو گروه ارائه شـده اسـت. جدول ا نشـاندهنده نتايج حاصـل از مقايسه ميانگين متغيرهاى جمعيتشناختى هر دو گروه است.
و اعتبار آن با روش كودر ريجارسون •Y، M \ • به دست آمده است و در

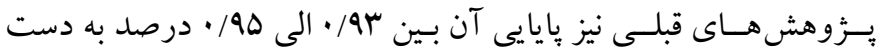
آمده اسـت. همجينين اعتبار و روايى درونى اين برسشنامه با مقياس بِاركا

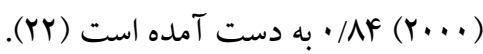
Y. برسششنامه رضامنلدى زوجيت I: اين مقياس توسط افروز در سال IMAV جهت ارزيابى ميزان رضـايت همسـران ساخته شده است. مقياس مذكور داراى · لا كويه بسـته ياسـخ در قالب F درجهاى ليكرت (كاملاً موافقم، مو افق، مخالف، و كاملاً مخالف) اسـت كه · ا خردهمقياس دارد و اعتبار

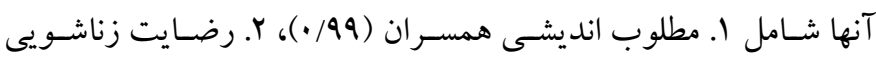

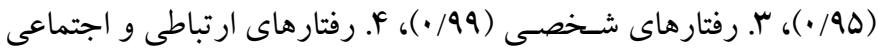
(99/•)، ه. روش حل مسئله (99/•)، 9. امور مالى و فعاليتهاى اقتصادى

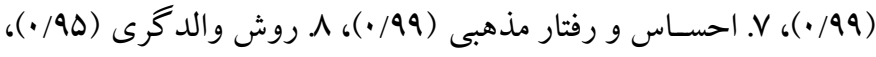
9. اوقات فراغت (9ه/•)، و · 1. تعامل احساسى (كلامى و بصرى) (99/•) است. براى بيى بردن به ميز ان رضايت زناشويى در كل مقياس، افرادى كه

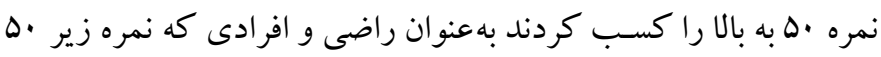
را كسـب كردند بهعنوان ناراضـى در نظر كرفته شـدند. همسـانى درونى كل اين مقياس برابر Ar/ •، روايى همزمان آن با مقياس رضايت زناشويى

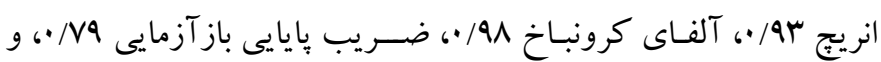
همسانى درونى برابر با 91/ • به دست آمدهاست (YY). ج) روش اجرا: براى اجراى اين بثروش بعد از كسب مجوزهاى للزم از دانشگاه محل تحصيل نويسنده نخست اين مقاله و دانشگاه علوم يزشكى إنى سـير جان به بخش زنان و زايمان بيمارسـتان امام رضــا (ع) شــهرســان

جدول ا: مقايسه ميانغين متغيرهاى جمعيتشناختى در دو كروه مطالعه

\begin{tabular}{|c|c|c|c|c|c|}
\hline \multirow{2}{*}{ سطح معنى دارى* } & \multicolumn{2}{|c|}{ كود كان با وزن بالا هنكام تولد } & \multicolumn{2}{|c|}{ كود كان با وزن كم هنغام تولد } & \multirow{2}{*}{ متغير } \\
\hline & انحر اف معيار & ميانكين & انحر اف معيار & ميانكين & \\
\hline$<\cdot / \cdot \cdot 1$ & $999 /$. & $r \Delta q \cdot / \Lambda$ & TFV/M & rMrI/. & وزن هنگًام تولد (كرم) \\
\hline$\%$ r. & . /9 & 1/9r & $\cdot / F V$ & $1 / F V$ & 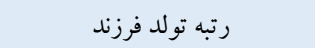 \\
\hline$\cdot / \cdot \mathrm{VI}$ & $\Delta / r Y$ & rN/. & r/AV & $r \Delta / 9$ & سن مادر هنگام زايمان (سال) \\
\hline$\cdot / 9 \cdot 4$ & $r / \Delta$ & $r Y / l$ & r/Tq & $r Y / r$. & سن مادر هنگام ازدواج (سال) \\
\hline . / IFF & $\Delta / r V$ & $r r / v$ & $r / \Lambda$ & $\mathrm{rl}_{\mathrm{l}} \cdot$ & سن يدر هنگًام زايمان مادر (سال) \\
\hline - /ATA & $r / .9$ & rQ/9 & r/YG & $r \& / 0$ & سن يدر هنگام ازدواج (سال) \\
\hline
\end{tabular}


نوزادان كموزن است. همسانى توزيع متغيرهاى رتبهاى زمينهاى (جنسيت

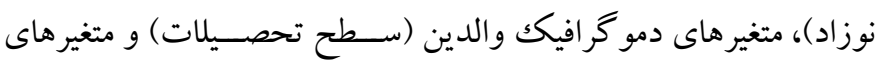

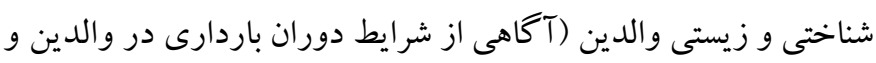

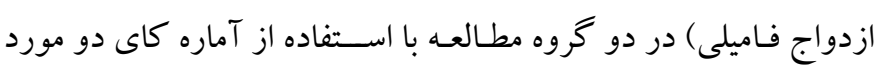

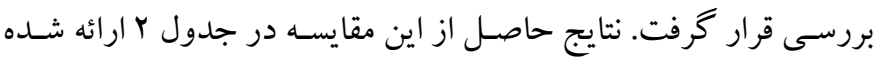

است.
همـان كونـه كـه در جدول ا مى توان مشــاهده كرد نتايج حاصـل از

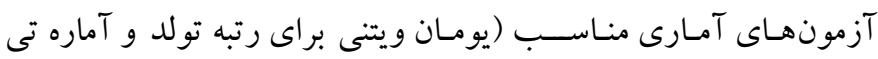

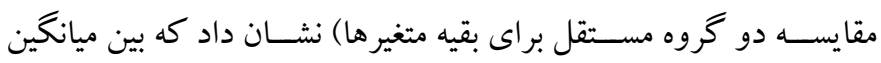

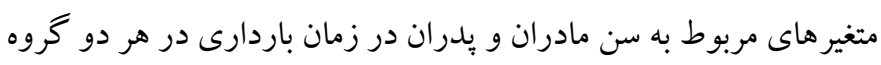

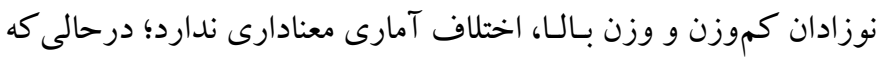

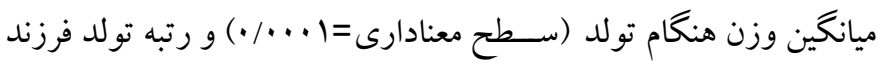

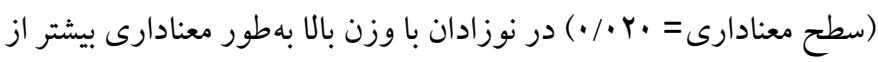

جدول r. ارتباط وضعيت ويزّى هاى شناختى و رضايتمندى با وزن نوزاد به هنعام تولد

\begin{tabular}{|c|c|c|c|c|c|c|}
\hline \multirow{2}{*}{ سطح معنىدارى* } & \multicolumn{2}{|c|}{ كود كان با وزن بالا هنغام تولد } & \multicolumn{2}{|c|}{ كود كان با وزن كم هنغام تولد } & \multirow{2}{*}{ سطح } & \multirow{2}{*}{ متغير } \\
\hline & درصد & تعداد & درصد & تعداد & & \\
\hline \multirow{3}{*}{.$/ . \Delta 1$} & $r F /$. & $\wedge$ & $r \cdot / \cdot$ & $\wedge$ & ضعيف & \multirow{3}{*}{ آكاهى مادر از شرايط دوران باردارى } \\
\hline & rN/. & 11 & ra/. & ir & متوسط & \\
\hline & $\mathrm{FN}$. & 19 & $F F /$. & 10 & خوب & \\
\hline \multirow{3}{*}{$.1 \cdot 19$} & $Y F /$. & 9 & $F \wedge / \cdot$ & 10 & ضعيف & \multirow{3}{*}{ آكاهى بدر از شرايط دوران باردارى } \\
\hline & YN/ & 11 & rq/. & ir & متوسط & \\
\hline & FN. & 10 & $19 /$. & $v$ & 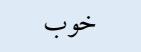 & \\
\hline \multirow{2}{*}{.$/ \cdot 1$} & $\Delta r / \cdot$ & ro & $\mathrm{F}_{\mathrm{N} /}$ & 1. & 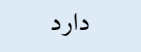 & \\
\hline & $F N /$ & 1. & $\Delta r / \cdot$ & ro & 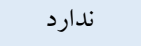 & \\
\hline \multirow{3}{*}{$\cdot / \mathrm{V} A$} & $\cdot /$ & & $F /$. & r & دييلم و كمتر & \multirow{3}{*}{ سطح تحصيلات مادر } \\
\hline & $\forall \wedge /$ & ir & $\Delta r / \cdot$ & 11 & 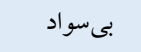 & \\
\hline & $\Delta r / \cdot$ & ir & $\kappa \kappa /$. & 10 & دانشگاهى & \\
\hline \multirow{2}{*}{$\cdot / \pi 9 \Delta$} & $4 \cdot \%$ & 10 & $\kappa \kappa /$. & 19 & دييلم و كمتر & \multirow{2}{*}{ سطح تحصيلات يدر } \\
\hline & $F \cdot /$. & 1. & $\Delta 9 /$. & 19 & دانشگاهى & \\
\hline
\end{tabular}

دو صـفت نيز در دو كروه نوزادان مورد مطالعه اختلاف آمارى معنادارى

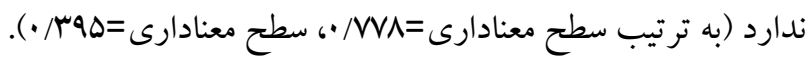
براى بررسى اثر همزمان متغيرهاى رستهاى و رتبهاى اين يثروهش بر وزن هنگام تولد نوزاد از تحليل ركرسيون لجستيك باينرى استفاده شد. لازم به ذكر است كه متغيرهاى زمينهاى و بيشتر متغيرهاى جمعيتشناختى بـه دليـل عدم معنادارى آمارى در تحليل يككمتغيره در مدل ركرســيون لجسـيكك به كار گرفته نشـدند. نتايج حاصـل از اين تحليل در جدول r ارائه شده است.
همـان كونـه كه جدول r نشــان مى بهد، آكاهى مادران از شــــايط دوران بـاردارى بين دو گروه از تفـاوت معنـادار برخوردار بوده اســت (ســطح معنادارى=اله •/•)، درحالى كه آكاهى بدران از شـــرايط دوران باردارى همسـرانشـان بهطور معنادارى از توزيع متفاوتى در بين دو گروه برخوردار بوده اســت (ســطح معنـادارى=19 • •). بهطورى كه آكَاهى تعداد بيشترى از يدران بانوزادان با وزن كم هنگام تولد (ها نوزاد، \&^٪)

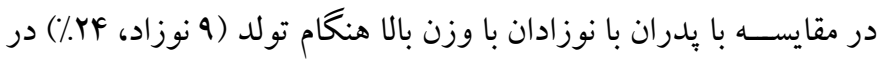
سـطح ضـعيف قرار دارد. نتيجه آزمون دقيق و آزمون كاى دو به ترتيب براى سطح تحصيلات مادر و سطح تحصيلات يدر نشان داد كه توزيع اين 
جدول "ا. برآورد ضرايب ركرسيونى متغيرهاى شناختى والدين مرتبط با وزن زمان تولد نوزادان بر اساس مدل لجستيك ركرسيون جند

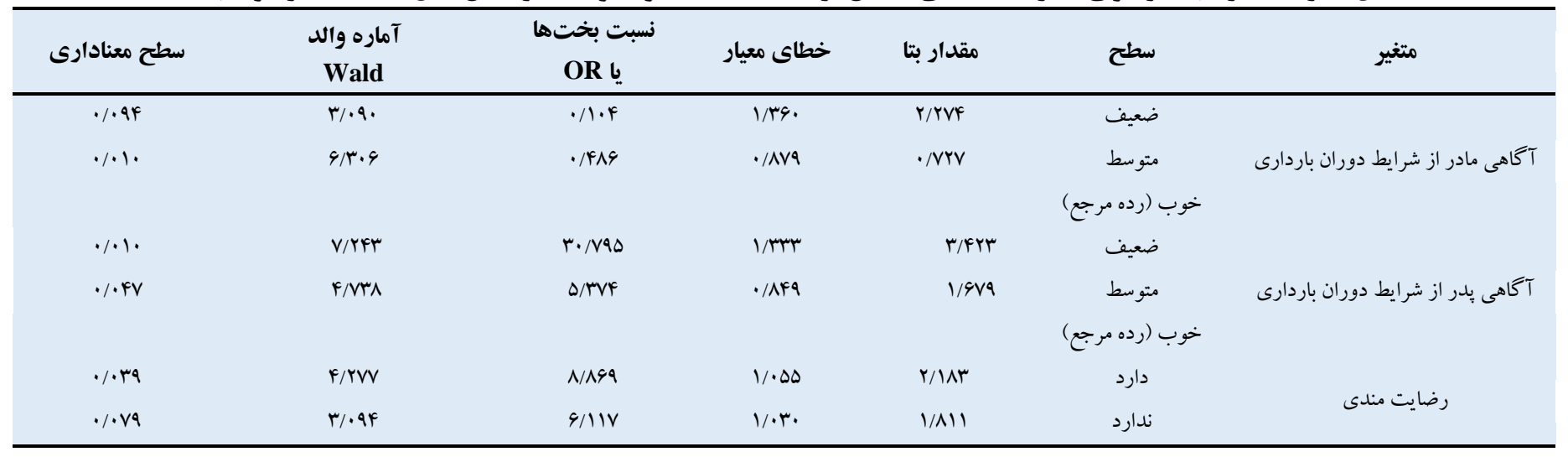

اسـاس آنها ييشبينى كرد. از آنجا كه وزن نوزاد به هنگام تولد از عوامل

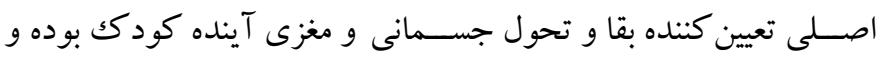

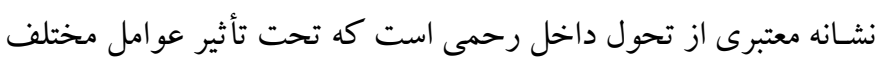

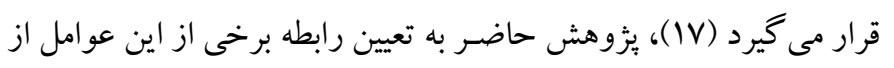

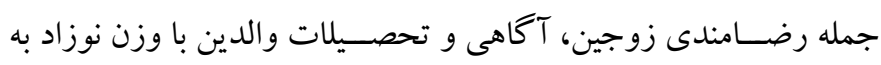

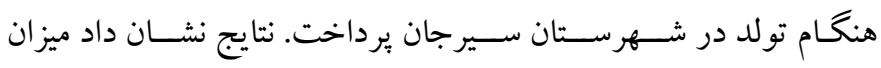

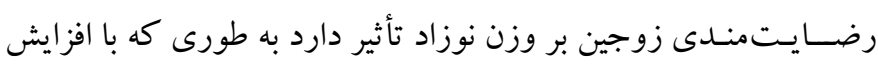

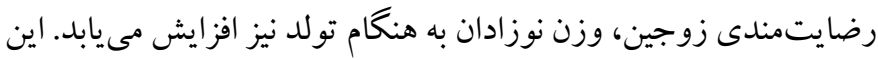

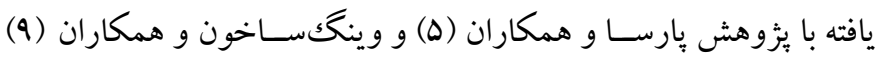

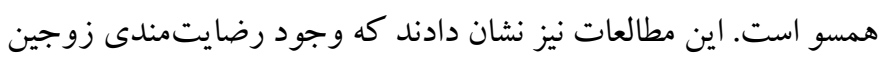
مى تواند بخش زيادى از سلامت روان جنين را فراهم سازد و همجنين بين

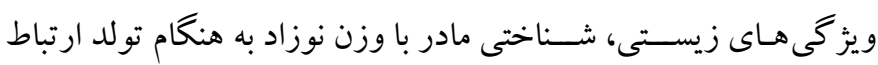

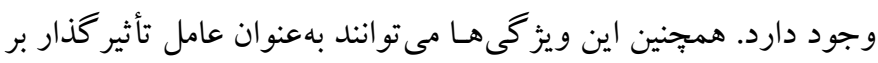

$$
\text { وزن نوزاد در نظر كرفته شوند. }
$$

رضامندى زوجين يكى از عوامل تعيين كننده ثبات و يايدارى خانو اده

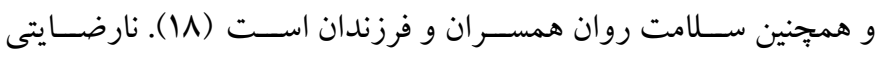
زناشويى بسيارى از زنان را در دوران باردارى دجار احساس آسيبيذيرى

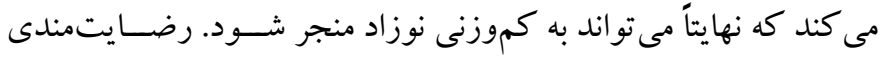

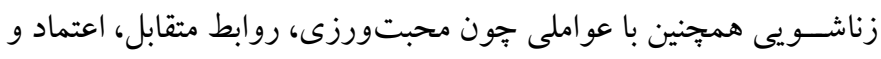

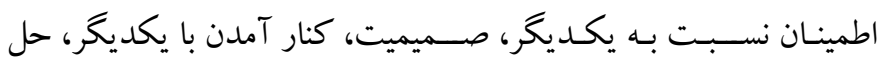
اختلاف، و جلب احسـاس طرفين نسبت به آينده رابطهى زناشويى، همراه

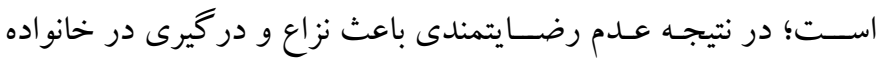

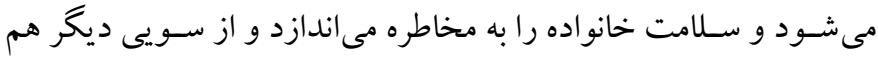

نتـايج ارائه شـــه در جدول ب بيانكر اثر معنادار متغير آكاهى يدر از

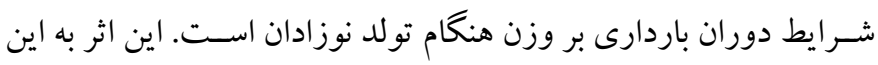

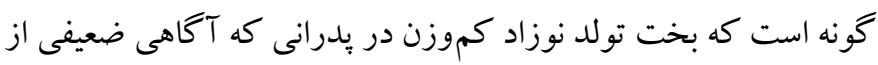

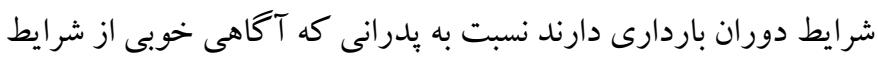

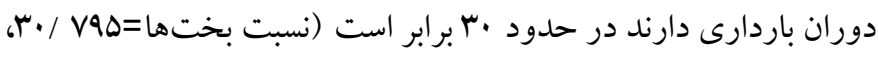

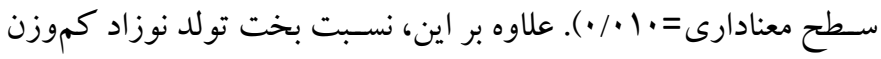

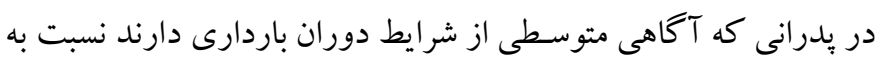

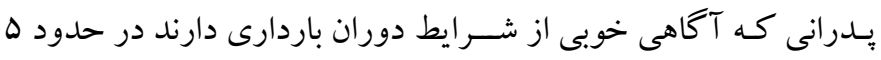

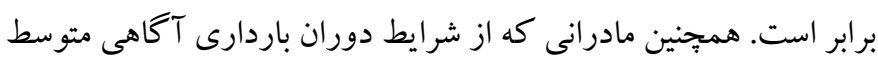

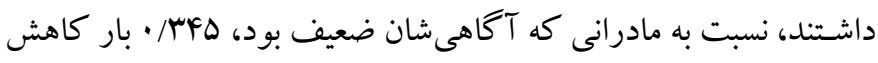

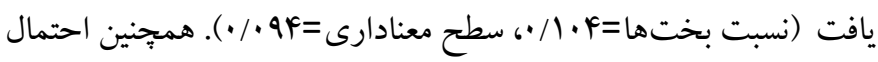

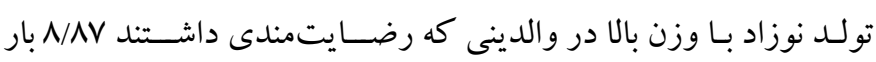

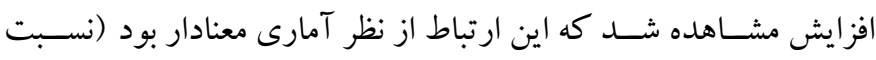

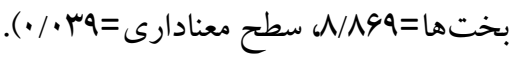

\section{بحث و نتيجه كيرى}

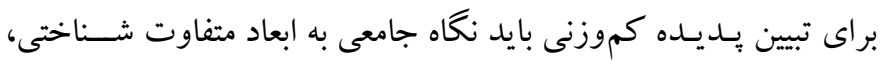

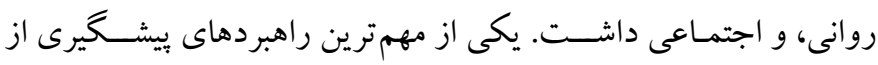

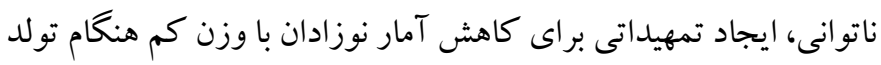

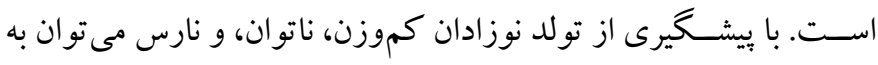

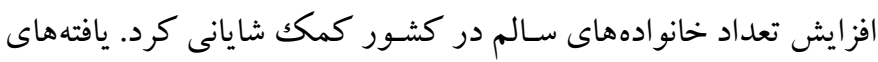

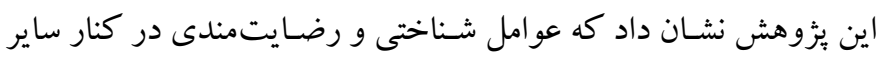

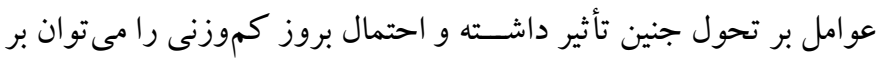


جايگاه ويزهاى را به خود اختصاص مىدهد. در اين رابطه نتايج مطالعات

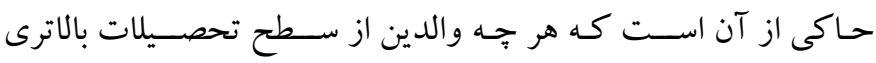

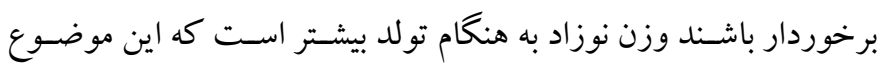

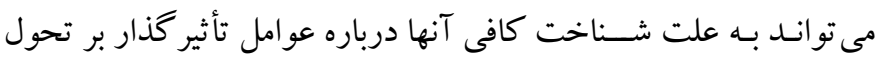

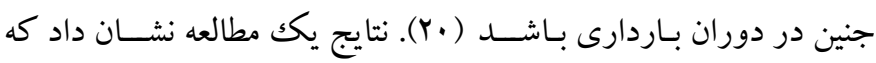

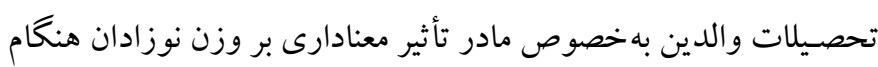

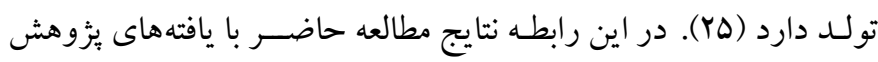

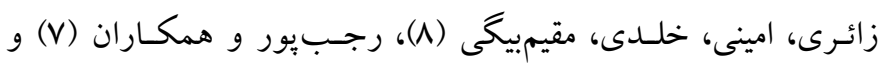

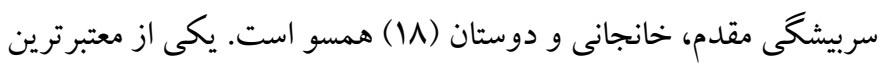
مدل ها براى توضيح اين مكانيسم توسط كميسيون عدالت سازمان جهانى

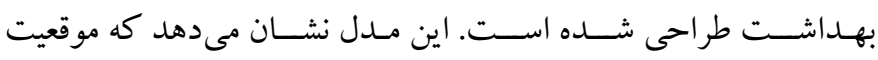
اجتماعى -اقتصـادى هر فرد بر سلامت او اثر مى گذارد، اما اين اثر مستقيم

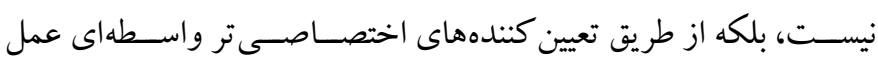

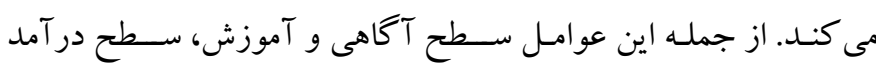

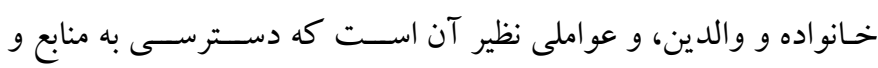

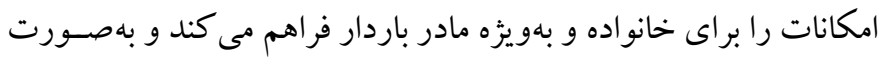

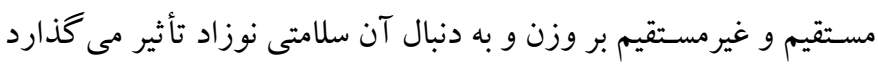

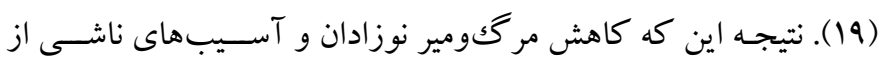
كموزنى هنگام تولد، نياز به بررسى همه جانبه و اجر ایى يكك برنامه مدون

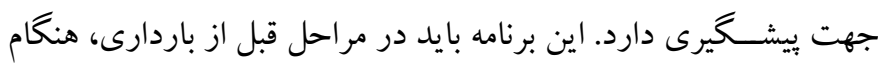
باردارى، حين زايمان، و بس از زايمان انجام شود.

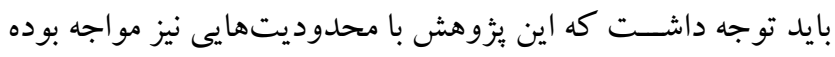

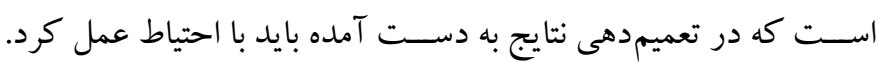

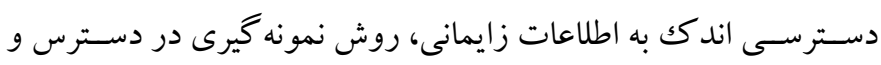

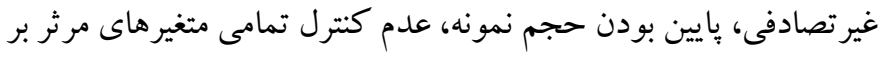

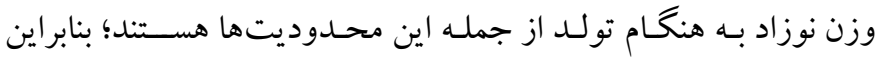

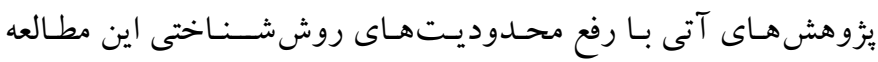

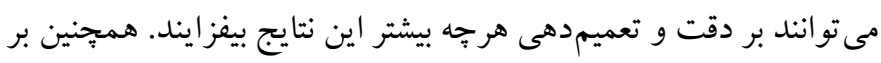

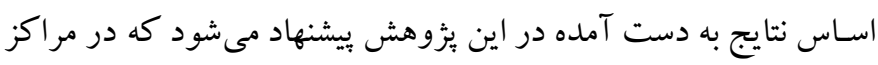

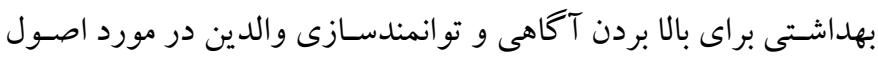

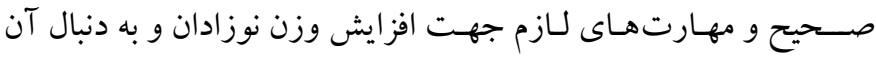

ممكن اسـت موجب تر كى خانو اده از سـوى يلدر شـود. همه اين عوامل باعث كاهش تو انايى مادر در دوران حســاس باردارى شــده كه مى تواند

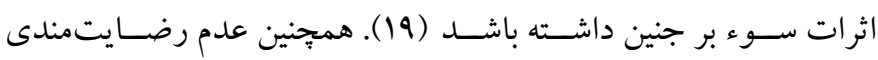

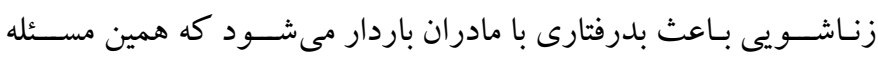

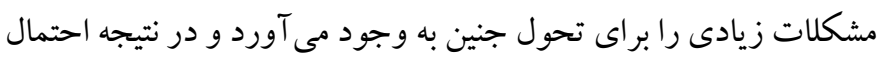

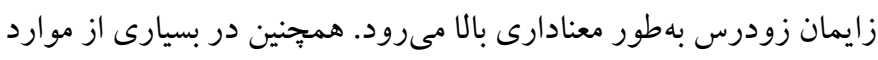
عدم رضايت مندى زناشويى موجب باردارى ناخو استه مى شود. ناخو استه بودن جنين نيز به نوبه خود عدم مر اقبت هاى كافى و بهداشـى رئى را به دنبال

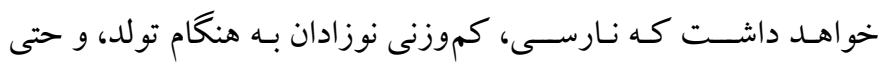

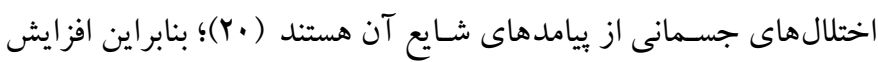

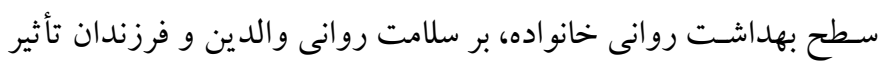
مهمى دارد. يافته ديخر اين بثزوهش درباره نقش ويز گیىهاى شناختى والدين بود.

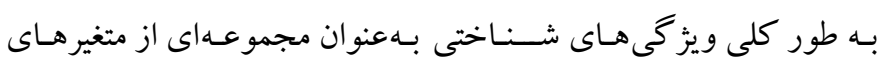

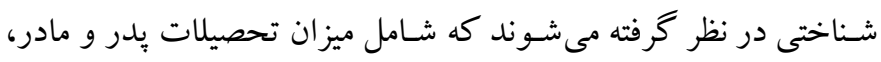
ميزان آكاهى بدر و مادر درباره كنش هاى حسى - حر كتى جنى جنين و نظاير

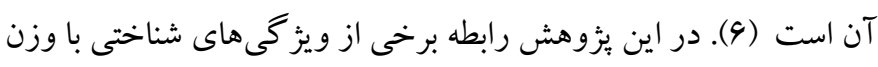

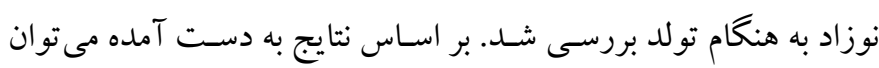

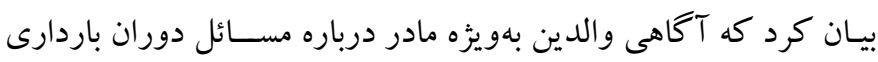

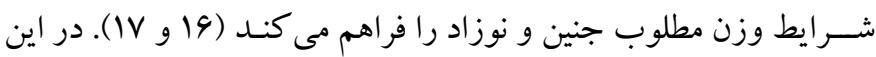

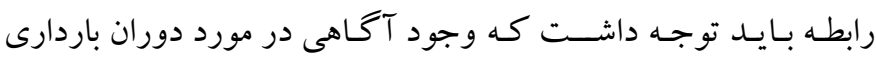

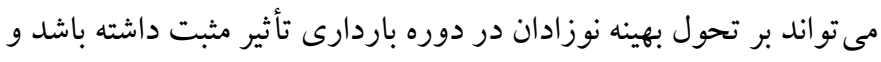
اين آكاهى موجب حفظ سـامت و رعايت مسـائل بهداشتى در بين زنان بـان

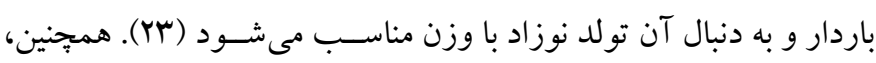

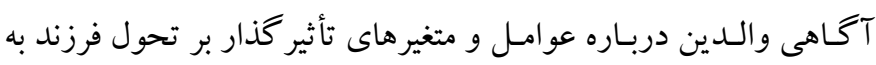

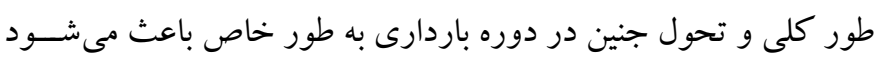

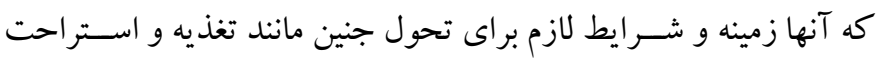

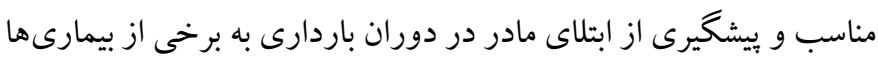

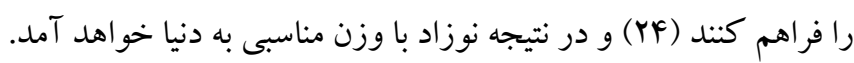

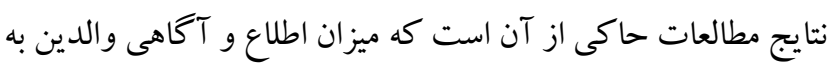

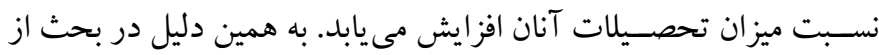
آكاهى والدين در مورد اهميت مراقبت هاى بيش از تولد، تحصيلات آنها 
است. بدينوسيله از كار كنان بيمارستان امام رضا (ع) و همجينين درمانگاههاى

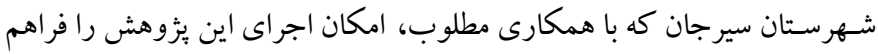

$$
\text { كردند، تشكر و قدردانى مى شود. }
$$

تضـاد منافع: انجام اين بزروهش هيجِ گونه تضـاد منافع را براى نويسـند كان به

$$
\text { دنبال نداشته است. }
$$

بيشخيرى از ناتو انى ها، برنامهها و دورههاى آموزشى مناسبى براى والدين قبل از اقدام به باردارى ترتيب داد.

تشــكر و قــدردانىى: اين بُروهش بركر فتـه از رســالـه دكتراى خانم فاطمه

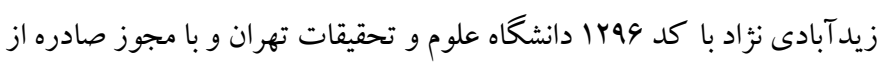

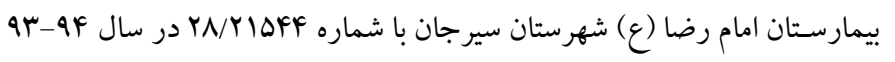




\section{References}

1. Acharya A, Santos J, Linde B, Anis K. Acute kidney injury in pregnancy-current status. Adv Chronic Kidney Dis. 2013; 20(3): 215-222. [Link]

2. Rasmussen KM, Abrams B, Bodnar LM, Butte NF, Catalano PM, Maria Siega-Riz A. Recommendations for weight gain during pregnancy in the context of the obesity epidemic. Obstet Gynecol. 2010; 116(5): 1191-1195. [Link]

3. West J, Lawlor DA, Fairley L, Wright J. Differences in socioeconomic position, lifestyle and health-related pregnancy characteristics between Pakistani and White British women in the born in Bradford prospective cohort study: the influence of the woman's, her partner's and their parents' place of birth. BMJ Open. 2014; 4(6):e004805. [Link]

4. Vahabi N, Zayeri F, FazeliMoghadam E, Safari M, Ebrahimzadeh F. Assessing the factors affecting height and weight trends among children under two years of age in Khorramabad: an application of marginal modeling. Iranian Journal of Epidemiology. 2015; 11(3): 52-61. [Persian]. [Link]

5. Parsa A, Afrouz G, Lavasani MG, Jashni Motlagh A. Relationship between marital Satisfaction of Pregnant Women and Infant Birth weight. Middle Eastern Journal of Disability Studies. 2017; 7(0): 88. [Persian]. [Link]

6. Abe K, Hamada H, Yamada T, Obata-Yasuoka M, Minakami H, Yoshikawa H. Impact of planning of pregnancy in women with epilepsy on seizure control during pregnancy and on maternal and neonatal outcomes. Seizure. 2014; 23(2): 112-116. [Link]

7. Rajabpour Farkhani S, Gholam Ali Lavasani M, Afrooz GA. The effectiveness of psychological interventions on infants' birth weight. Journal of Clinical Psychology Andishe Va Raftar (Applied Psychology). 2017; 11(42): 57-66. [Persian]. [Link]

8. Zayeri F, Amini M, Kholdi N, Moghimbeigi A. Determination of factors affecting growth failure of children under two years with multilevel logistic regression model. Daneshvar. 2014; 21(112): 41-48. [Persian]. [Link]

9. Viengsakhone L, Yoshida Y, Harun-Or-Rashid M, Sakamoto J. Factors affecting low birth weight at four central hospitals in vientiane, Lao PDR. Nagoya $\mathbf{J}$ Med Sci. 2010; 72(1-2): 51-58. [Link]

10. Stamnes Koepp UM, Frost Andersen L, DahlJoergensen K, Stigum H, Nass O, Nystad W. Maternal pre-pregnant body mass index, maternal weight change and offspring birthweight. Acta Obstet Gynecol Scand. 2012; 91(2): 243-249. [Link]

11. Bahiraii A, Faghihi Rad S, Mirmohammadali M, Kazem Nezhad A. Predictors of home smoking ban in households in pregnant women. Payesh (Health Monitor). 2012; 11(4): 511-517. [Persian]. [Link]

12. Akinkuotu AC, Nuthakki S, Sheikh F, Cruz SM, Welty SE, Olutoye OO. The effect of supplemental parenteral nutrition on outcomes of necrotizing enterocolitis in premature, low birth weight neonates. Am J Surg. 2015; 210(6): 1045-1049; discussion 1049-1050.[Link]

13. Esmaeilpour K, khajeh V, Mahdavi N. Predicting couples' marital satisfaction based on relationship beliefs and relationship skills. Journal of Family Research.2013; 9(1): 29-44. [Persian]. [Link]

14. Toosi M, Akbarzadeh M, Zare N, Sharif F. The role of relaxation training to pregnant mothers on health index of infants. Journal of Jahrom University of Medical Sciences. 2013; 11(1): 15-21. [Persian]. [Link]

15. Rostami AM, Cheraghali Gol H. Prediction of Marital Satisfaction based on Spiritual Intelligence. Procedia Soc Behav Sci. 2014; 116: 2573-2537. [Link]

16. Vahabzadeh D, Karandish M, Eftekhari J, Haghighizadeh MH, Altabib H. Risk factors of growth faltering among 3-36 months old children in Ahwaz, Iran. Journal of Kerman University of Medical Sciences. 2013; 20(5): 481-491. [Persian]. [Link]

17. Suzuki K. Longitudinal analyses of childhood growth: evidence from Project Koshu. J Epidemiol. 2015; 25(1): 2-7. [Link]

18. Sarbishehgi Moghadam M, Khanjani N, Doostan F. Environmental factors associated with growth delay among 3-72 month old children in Sarbisheh, south Khorasan province, 2013. Journal of Neyshabur University of Medical Sciences. 2016; 4(1): 30-40. [Persian]. [Link]

19. Epstein MB, Bates MN, Arora NK, Balakrishnan K, Jack DW, Smith KR. Household fuels, low birth weight, and neonatal death in India: the separate impacts of biomass, kerosene, and coal. Int $\mathbf{J}$ Hyg Environ Health. 2013; 216(5): 523-532. [Link]

20. Zare Neyestanak M, GholamaliLavasani M, Afrooz G. The relationship between maternal biosocial determinants and infant birth weight. Journal of Midwifery and Reproductive Health. 2017; 5(3): 935-941. [Link] 
21. Mohammadi E, Bagheri M, Asgarizadeh G. The role of perceived social support and aspects of personality in the prediction of marital instability: the mediating role of occupational stress. International Journal of Psychology (IPA). 2018; 12(1): 162-185. [Link]

22. Talebian MH, Afrooz GA, Hooman HA, Aghaei A. The relationship between biological cognitive and psychosocial characteristics of mothers and the weight of infant at the time of birth in Isfahan province. Journal of Woman \& Hygiene. 2010; 1(3): 85-100. [Persian]. [Link]
23. Vameghi M, Sajadi H, Rafiey H, Qaedamini Q. The role of parental education and intermediary determinants on children's health in Iran. Razi Journal of Medical Sciences. 2016; 23(147): 18-34. [Persian]. [Link]

24. Lechtig A, Yarbrough C, Delgado H, Habicht JP, Martorell R, Klein RE. Influence of maternal nutrition on birth weight. Am J Clin Nutr. 1975; 28(11): 1223 1233. [Link]

25. Halperin IJ, Feig DS. The role of lifestyle interventions in the prevention of gestational diabetes. Curr Diab Rep. 2014; 14(1): 452. [Link] 